\title{
PARTISIPASI MASYARAKAT DALAM PEMBENTUKAN PROGRAM LEGISLASI DAERAH
}

\author{
Yusdiyanto
}

Dosen Bagian HTN Fakultas Hukum Universitas Lampung

\begin{abstract}
ABSTRAK
Penulisan ini dilakukan untuk menjawab Pasal 35 Ayat (4) Undang-Undang Nomor 12 Tahun 2011 tentang Pembentukan peraturan perundang-undangan yang menyebutkan bahwa pembentukan Program Legislasi Daerah (Prolegda) berdasarkan aspirasi masyarakat daerah. Sesuai ketentuan perundang-undangan, daerah diberikan kewenangan yang begitu besar, namun persoalan berikutnya adalah bagaimana mendorong tata pemerintahan lokal yang demokratis (democratic governance). Salah satunya dengan mendorong partisipasi masyarakat melalui pembentukan Prolegda. Problematika dari partisipasi masyarakat dalam pembentukan Peraturan Daerah meliputi tiga hal yaitu : permasalahan yuridis, birokrasi dan masyrakat. Partisipasi merupakan pemberian ruang terhadap hak masyarakat untuk memberi masukan dalam Prolegda, dengan secara bersamaan mewajibkan Pemerintah daerah dan Dewan Perwakilan Rakyat Daerah (DPRD) mempermudah masukan mengenai Pembentukan Prolegda. Prolegda merupakan dokumen perencanaan yang dipersiapkan secara dan bersama-sama oleh lembaga pemerintahan daerah dengan mengikuti ketentuan hukum yang sudah ditentukan. Peran serta masyarakat dalam proses penyusunan Prolegda dilaksanakan dengan memperhatikan asas keterbukaan dan prinsip akses informasi serta partisipasi. Dikarenakan hak masyarakat dalam berpartisipasi telah dijamin dan diberikan dalam Undang-Undang atau Perda yang merupakan amanat UUD, yang pada akhirnya akan dihasilkan Perda yang transparansi dan partisipasi dalam penyelenggaraan pemerintahan Daerah.
\end{abstract}

\section{Kata Kunci : Pemerintahan Daerah, Partisipasi dan Prolegda}

\section{PENDAHULUAN}

Persoalan mendasar dari kehidupan bernegara dalam proses penyelenggaran pemerintah baik di tingkat pusat maupun daerah adalah bagaimana membangun atau menciptakan mekanisme pemerintahan yang dapat mengemban visi-misi untuk mewujudkan raison de'etre pemerintahan yaitu mensejahterakan masyarakat secara berkeadilan.
Era reformasi telah membuka babak baru bagi Indonesia hampir disegala bidang kehidupan. Problematika Pemerintahan Daerah terus muncul sebagai suatu realitas yang secara yuridis membutuhkan kajian keilmuan yang mendalam. Pemerintah cenderung mengalami kesulitan yang bersifat praktis yang selama ini tidak muncul dalam penyelenggaraan pemerintahan sebelum era reformasi bergulir 
melahirkan

Undang-Undang

Pemerintahan Daerah. ${ }^{1}$

Pasal 18 ayat (6) UUD 1945, mengatakan Pemerintah Daerah berhak menentukan Peraturan Daerah dan peraturan-peraturan lain untuk melaksanakan otonomi dan tugas pembantuan. Adapun pengertian Peraturan Daerah menurut Yuswanto, ${ }^{2}$ meliputi Perda dan peraturan-peraturan lain, seperti peraturan gubernur, peraturan bupati atau peraturan walikota.

Perda merupakan peraturan perudang-undangan tingkat daerah, dibentuk oleh lembaga pemerintah di tingkat daerah dalam rangka penyelenggaraan otonomi daerah yang secara tegas ada dalam Pasal 18 ayat (6) UUD 1945 yang keberadaannya ada dalam sistem hukum di negara Republik Indonesia. $^{3}$ Pasal 136 UndangUndang No. 32 Tahun 2004, mengatakan Perda dibentuk dalam kerangka penyelenggaraan otonomi daerah provinsi/kabupaten/ kota dan tugas pembantuan, merupakan penjabaran dari peraturan perundangundangan yang lebih tinggi dengan memperhatikan ciri khas masingmasing daerah.

Dewan Perwakilan Rakyat Daerah (DPRD) memiliki fungsi legislasi yang menempatkan produk

${ }^{1}$ Akmal Boedianto, 2010. Hukum Pemerintahan Daerah: Pembentukan Perda APBD Partisipatif. Yogyakarta: LaksBang PRESSindo. Hlm 4

2 Yuswanto. 2009. Otonomi Daerah Dalam Konstitusi., Bahan ajar perkuliahan otonomi daerah Pasca Sarjana FH UNILA. hlm 7.

${ }^{3}$ Maria Farida. 2005. Kedudukan Peraturan Daerah dalam Sistem Hukum di Negara Republik Indonesia. Makalah disajikan pada acara Temu Konsultasi Penyusunan Program Legislasi Daerah, yang diselenggarakan oleh Badan Pembinaan Hukum Nasional, Departemen Hukum dan HAM, di Sanur, Bali. hlm 13 legislasi bagian dari sistem hukum nasional. Perda tunduk pada prinsipprinsip dasar atau asas-asas dalam sistem hukum nasional artinya pembentukan legislasi daerah berangkat dari suasana kebatinan daerah yang bersumber dari Pancasila dan Undang-Undang Dasar sehingga tidak keluar dari sistem hukum nasional. Pancasila dan UUD 1945 ditempatkan sebagai sumber hukum dan cita hukum (rechtsidee) Perda. Mekanisme pembentukan Perda harus mencerminkan asas-asas umum dalam sila-sila Pancasila yaitu: asas ketuhanan, asas kemanusian, asas persatuan, asas kerakyatan dan asas keadilan sosial.

Perumusan Prolegda menurut Pasal 1 ayat (10) Undang-Undang No. 12 Tahun 2011 mengatakan Program Legislasi Daerah yang selanjutnya disebut Prolegda adalah instrumen perencanaan program pembentukan Peraturan Daerah Provinsi atau Peraturan Daerah Kabupaten/Kota yang disusun secara terencana, terpadu, dan sistematis. ${ }^{4}$ Pasal 32 sampai dengan Pasal 39 Undang-Undang No. 12 Tahun 2011 menyatakan

Perencanaan Penyusunan Peraturan Daerah Provinsi dilakukan dalam Prolegda Provinsi. Perencanaan Penyusunan Peraturan Daerah Kabupaten/Kota dilakukan dalam Prolegda Kabupaten/Kota. ${ }^{5}$

Maksud Prolegda sebagai instrumen perencanan legislasi yang disusun secara terencana, terpadu dan sistematis adalah: terencana

\footnotetext{
${ }^{4}$ Lihat Undang-Undang No. 12 Tahun 2011 tentang Pembentukan Peraturan PerundangUndangan Lembaran Negara Republik Indonesia Tahun 2011 Nomor 82.

5 Lihat penjelasan Undang-Undang No. 12 Tahun 2011, Tambahan Lembaran Negara Republik Indonesia Nomor 5234.
} 
maksudnya perumusan Prolegda disiapkan terlebih dahulu secara baik, misalnya melalui kajian akademik sebagaimana telah diperintahkan dalam UndangUndang No. 12 Tahun 2011. Terpadu maksudnya pembentukan Prolegda dilakukan secara bersamasama dan bersinergi antara baik dari Pemerintah Daerah maupun DPRD, dengan melibatkan para pemangku kepentingan. Sistematis maksudnya pembentukan Prolegda mengikuti ketentuan hukum dan dilakukan menggunakan mekanisme yang sistemik. Dari penjelasan tersebut arti penting Prolegda merupakan dokumen perencanaan yang dipersiapkan secara baik, dilakukan secara bersama-sama dan mengikuti ketentuan hukum yang sudah ditentukan.

Sebagai instrumen perencanaan legislasi maka dapat diketahui secara publik, politik hukum Pemerintahan Daerah dalam rangka melaksanakan pembangunan daerah selama satu tahun berjalan. Prolegda diharapkan mampu menjaga Perda berada dalam kesatuan sistem hukum nasional.

Menurut Pasal 2 ayat (2), (4) dan (5), Undang-Undang No. 32 Tahun 2004 tentang Pemerintahan Daerah, menyatakan Pemerintahan Daerah mengatur dan mengurus sendiri urusan pemerintahan menurut asas otonomi dan tugas pembantuan. ${ }^{6}$

\footnotetext{
${ }^{6}$ Maksudnya prinsip otonomi daerah menggunakan prinsip otonomi seluasluasnya dalam arti daerah diberikan kewenangan mengurus dan mengatur semua urusan pemerintahan di luar yang menjadi urusan Pemerintah yang ditetapkan dalam Undang-Undang ini. Daerah memiliki kewenangan membuat kebijakan daerah untuk memberi pelayanan, peningkatan peranserta, prakarsa, dan pemberdayaan masyarakat yang bertujuan pada peningkatan kesejahteraan rakyat. Lihat penjelasan
}

Pemerintahan daerah menyelenggarakan urusan pemerintahan memiliki hubungan antara Pemerintah dan dengan pemerintah daerah lainnya. Hubungan sebagaimana dimaksud tersebut meliputi hubungan kewenangan, keuangan, pelayanan umum, pemanfaatan sumber daya alam, dan sumber daya lainnya. ${ }^{7}$

Undang-Undang No. 32 tahun 2004 memberikan rumusan kepada Pemerintah Daerah bahwa penyelengaraan Pemerintahan Daerah perlu direncanakan sesuai dengan kewenangan atau urusan yang diberikan oleh Pemerintah Pusat kepada Pemerintah Daerah. Demikian pula pembentukan Prolegda harus berdasarkan dengan ketentuan Undang-Undang No. 32 Tahun 2004, yang berkaitan dengan hubungan kewenangan antara pemerintah pusat dan pemerintah daerah yaitu kewenangan yang didistribusikan pemerintah pusat kepada pemerintah daerah dan tugas pembantuan (medebewind).

Kesemua persoalan tersebut dikarenakan sistem pembentukan peraturan perundang-undangan mengabaikan pentingnya kegiatan inventarisasi, sinkronisasi dan harmonisasi seluruh peraturan perundang-undangan, serta kurang melakukan diseminasi peraturan perundang-undangan untuk membuka akses seluas-luasnya dan meningkatkan partisipasi masyarakat dalam pembentukan Peraturan Daerah.

Melalui Undang-Undang No. 12 Tahun 2011 tentang Pembentukan Peraturan Perundang-Undangan,

Undang-Undang No. 32 Tahun 2004 tentang Pemerintahan Daerah, Tambahan Lembaran Negara RI Nomor 4437.

${ }^{7}$ Ibid, Lembaran Negara RI Nomor 125. 
yang salahsatu pengaturannya mendudukkan perencanaan legislasi pada tiap tingkatan peraturan perundang-undangan tersebut. $^{8}$ Perencanaan pembentukan peraturan perundang-undangan meliputi: Perencanaan Undang-Undang, Perencanaan Peraturan Pemerintah, Perencanaan Peraturan Presiden, Perencanaan Peraturan Daerah Provinsi dan Perencanaan Pemerintah Daerah Kota/Kabupaten dan Perencanaan Peraturan Perundang-Undangan (kelembagaan negara) lainnya. ${ }^{9}$

Melihat dinamika politik hukum masyarakat yang kian berkembang dan arah pembangunan hukum daerah yang kian besar, maka Prolegda dibutuhkan sebagai alat penataan dan pengelolaan sistem pembangunan hukum daerah yang dilakukan secara terencana, terpadu dan sistematis.

Besarnya kewenangan yang dimiliki daerah tentu akan mendatangkan manfaat yang besar bagi masyarakat apabila pemerintah daerah mampu membangun demokrasi ditingkat lokal (local level democracy) melalui peningkatan partisipasi publik. ${ }^{10}$ Ringkasnya partisipasi publik dapat mewujudkan tiga elemen penting yang harus dicapai yaitu demokrasi, partisipasi dan akuntabilitas. ${ }^{11}$

8 Lihat Pasal 7 Undang-Undang No. 12 tahun 2011, Ibid, hlm 6-7

9 Maksudnya perencanaan yang merupakan kewenangan dan disesuaikan dengan kebutuhan lembaga, komisi, atau instansi masing-masing.

${ }^{10}$ Erwan Agus Purwanto, Pelayanan Publik Partisipatif, dalam Agus Dwiyanto, 2006. Mewujudkan Good Governance Melalui Pelayanan Publik. Yogyakarta; Gajah Mada University Press. hlm 192

${ }^{11}$ Ibid
Setelah diberikan kewenangan yang begitu besar terhadap daerah, kini yang menjadi tugas selanjutnya adalah bagaimana mendorong tata pemerintahan local yang demokratis (democratic governance). Maksud dari democratic governance adalah dengan melihat pada :

1. Cara pandang baru terhadap pengelolaan tata pemerintahan maupun relasi negara, masyarakat dan pasar.

2. Dinamika empiris dan wacana akademis pengelolaan negara berhadapan dengan masyarakat dan pasar dalam konteks globalisasi, demokrasi dan desentralisasi; dan

3. Isu-isu geovernance reform yang berkaitan dengan konsep good governance yang sedang hangat dibahas di Indonesia saat ini.

Partisipasi masyarakat merupakan bagian penting dalam proses demokratisasi yang tengah berjalan di daerah, tidak hanya sebagai pengejawantahan dari asas keterbukaan yang melandasi sebuah negara demokratis, tetapi juga merupakan perwujudan dari perlindungan hak asasi masyarakat untuk ikut aktif dalam pemerintahan.

Sri Soemantri M., mengatakan ide demokrasi menjelmakan dirinya dalam lima hal, dua diantaranya adalah pemerintah harus bersikap terbuka (openbaarheid van bestur) dan dimungkinkannya rakyat yang berkepentingan menyampaikan keluhannya mengenai tindakantindakan pejabat yang dianggab merugikan. ${ }^{12}$

Philipus M. Hadjon mengatakan konsep partisipasi masyarakat berkaitan dengan konsep

12 Sri Soemantri M., 1992, Bunga Rampai Hukum Tata Negara Indonesia, Bandung: Alumni. hlm 29 
keterbukaan. Dalam artian, tanpa keterbukaan pemerintahan tidak mungkin masyarakat dapat melakukan peran-serta dalam kegiatan-kegiatan pemerintahan. ${ }^{13}$

Dari beberapa pengamatan pelaksanaan otonomi daerah problematika dari partisipasi masyarakat dalam pembentukan Peraturan Daerah meliputi tiga hal yaitu : Problem yuridis, birokrasi dan masyrakat. Pertama Yuridis meliputi: banyak peraturan yang belum berpihak masyarakat, belum ada aturan yang mengharuskan partisipasi masyarakat, ada aturan belum mengikat, Perda kewajiban tapi mengabaikan hak rakyat, Kurangnya sosialisasi aturan atau kebijakan. Kedua Birokrasi meliputi: birokrasi yang belum memberi ruang bagi publik, mesin birokrasi bekerja hanya pada jalur yang mereka ketahui/tetapkan, birokrasi melihat partisipasi sebagai biaya yang tinggi, pemahaman birokrasi tentang partisipasi kurang, saluran aspirasi kurang baik, peran partai kurang maksimal, dan mobilisasi/bukan partisipasi.

Ketiga Masyarakat meliputi: sikap apatis masyarakat, kurangnya pengetahuan dan pemahaman, budaya paternalistik masih kuat, tidak ada rekaman tindak lanjut partisipasi masyrakat, responsibilitas kurang, belum mengetahui mekanisme penyaluran dan akses informasi terbatas.

Pembentukan peraturan perundang-undangan termasuk Perda, sebagaimana diatur dalam Undang-Undang No. 12 Tahun 2011,

13 Philipus M. Hadjon, 1997. Keterbukaan Pemerintahan dalam Mewujudkan Pemerintahan yang Demokratis, Pidato, diucapkan dalam Lustrum III Ubhara Surya. hlm $4-5$ mulai dari: persiapan, perencanaan, pembentukan, pembahasan dan pengesahan, pengundangan dan penyebarluasan, dan mekanisme pembentukan peraturan perundangundangan. Pembentukan Perda memperhatikan visi dan misi kepala daerah dan rencana pembangunan daerah. ${ }^{14}$ Pasal 35 ayat (4) UndangUndang No. 12 Tahun 2011 menyatakan pembentukan Prolegda berdasarkan aspirasi masyarakat daerah.

Terhadap ketentuan normatif tersebut bagaimana hak masyarakat dan partisipasi masyarakat sipil dalam pembentukan Prolegda sehingga lahirlah Peraturan Daerah yang partisipatif.

\section{PEMBAHASAN}

\subsection{Pengertian Partisipasi}

Secara etimologis partisipasi berasal dari Bahasa Inggris kata 'participation' yang artinya pengambilan bagian. Menurut bahasa Belanda disebut 'participatie' yang artinya penyertaan. Bahasa Indonesia kemudian menerjemahkan Partisipasi sebagai perihal turut berperan serta dalam suatu kegiatan. Dengan demikian ada dua hal pokok dalam partisipasi yakni mengambil bagian dan penyertaan atau berperanserta.

Partisipasi berarti memberikan hak kepada masyarakat untuk memberi masukan dalam pembentukan Prolegda, secara bersamaan mewajibkan Pemda dan DPRD mempermudah masukan tersebut sampai pada mereka. ${ }^{15}$

\footnotetext{
${ }^{14}$ Lihat Undang-Undang No. 32 Tahun 2004 op cit, yang berkaitan dengan tugas, fungsi dan kewajiban kepala daerah.

${ }^{15}$ R. Siti Zuhro, Lilis Mulyani, Fitria, 2010. Kisruh Peraturan Daerah: Mengurai
} 
Partisipasi bisa bersifat transitif atau intrasitif, bisa pula bermoral atau tak bermoral, juga bisa bersifat dipaksa atau bebas, dan bisa pula bersifat manipulatif maupun spontan. ${ }^{16}$ Perumusan definisi partisipasi masyarakat diarahkan sebagai :

1. Partisipasi sebagai kebijakan partisipasi sebagai prosedur konsultasi para pembuat kebijakan kepada masyarakat sebagai subyek Perda.

2. Partisipasi sebagai strategi untuk mendapat dukungan Masyarakat demi kredibilitas kebijakan.

3. Partisipasi sebagai alat komunikasi agar pemerintah mengetahui keinginan rakyat, dan.

4. Partisipasi sebagai alat penyelesaian sengketa dan toleransi atas ketidakpercayaan dan kerancuan yang ada di masyarakat.

Pemberlakuan otonomi daerah, ${ }^{17}$ secara normatif, merupakan peluang membuka ruang partisipasi masyarakat dalam proses penyusunan dan implementasi kebijakan. Secara konseptual partisipasi merupakan implementasi dari sistem pemerintahan demokrasi dari rakyat oleh rakyat dan untuk rakyat. ${ }^{18}$

\subsection{Hak Masyarakat dalam Partisipasi}

Negara Republik Indonesia adalah negara yang berkedaulatan

Masalah dan Solusinya. Yogyakarta: Penerbit Ombak. hlm 51

${ }^{16}$ Khairul Muluk, 2006. Desentralisasi dan Pemerintahan Daerah. Jakarta: Penerbit Bayumedia. hlm. 43.

${ }^{17}$ Lihat Pasal 1 ayat (5) UU No. 32 Tahun 2004.

18 http://id.wikipedia.org/wiki/Demokrasi, diunduh tanggal 6 oktober 2011. rakyat. Kedaulatan rakyat dilaksanakan menurut ketentuan Undang Undang Dasar. Pasal 1 Ayat (3) UUD menyatakan menjamin pelaksanaan kedaulatan rakyat, dengan menerapkan asas-asas yang terdapat dalam prinsip2 negara hukum yaitu : Asas pengakuan dan perlindungan HAM, asas peradilan yang bebas dan tidak memaksa, pembagian kekuasaan, legalitas, kedaulatan rakyat, konstitusional dan asas demokrasi.

Undang-Undang No. 32 Tahun 2004 tentang Pemerintahan Daerah bahwa penyelenggaraan pemerintahan daerah sesuai dengan amanat Undang-Undang Dasar 1945, pemerintahan daerah mengatur dan mengurus sendiri urusan pemerintahan menurut asas otonomi dan tugas pembantuan, diarahkan mempercepat terwujudnya kesejahteraan masyarakat melalui peningkatan, pelayanan, pemberdayaan, dan peran serta masyarakat, serta peningkatan daya saing daerah dengan memperhatikan prinsip demokrasi, pemerataan, keadilan, keistimewaan dan kekhususan suatu daerah dalam sistem Negara Kesatuan Republik Indonesia. Pasal 139 ayat (1) Undang-Undang No. 32 Tahun 2004, mengatakan masyarakat berhak memberikan masukan secara lisan atau tertulis dalam rangka penyiapan atau pembahasan rancangan Peraturan Daerah. ${ }^{19}$

Undang-Undang No. 14 Tahun 2008 tentang Keterbukaan Informasi Publik dalam konsideran menimbang poin $b$ menyatakan bahwa hak memperoleh informasi publik merupakan hak asasi manusia dan

\footnotetext{
19 Undang-Undang No. 32 Tahun 2004 op cit
} 
keterbukaan informasi merupakan salah satu ciri penting suatu negara demokratis yg menjunjungtinggi kedaulatan rakyat untuk mewujudkan penyelenggaraan negara yang baik. Poin c menyatakan keterbukaan informasi publik merupakan sarana pengawasan publik terhadap penyelenggaraan negara.

Ketentuan yuridis mengenai partisipasi masyarakat sebelumnya diatur dalam Undang-Undang No. 10 Tahun 2004 namun kembali ditegaskan dalam Undang-Undang No. 12 Tahun $2011^{20}$ yaitu: (1) Masyarakat berhak memberikan masukan secara lisan dan/atau tertulis dalam Pembentukan Peraturan Perundang-undangan. (2) Masukan secara lisan dan/atau tertulis sebagaimana dimaksud pada ayat (1) dapat dilakukan melalui: a) Rapat dengar pendapat umum; b) Kunjungan kerja; c) Sosialisasi; dan/atau d) Seminar, lokakarya, dan/atau diskusi.

Peran serta masyarakat dalam proses penyusunan Peraturan Daerah dilaksanakan dengan memperhatikan prinsip akses informasi dan partisipasi. $^{21}$

\section{Akses Informasi ${ }^{22}$}

Pemerintah daerah wajib menyebarluaskan rancangan atau peraturan perundang-undangan tingkat daerah. Penyebarluasan bagi Perda dan Peraturan PerundangUndangan dibawahnya dilakukan

${ }^{20}$ Pasal 96 Undang-Undang No. 12 Tahun 2011 tentang Pembentukan Peraturan Perundang - Undangan

21 Departemen Hukum dan Hak Asasi Manusia RI, 2009. Panduan Praktis Memahami Perancangan Peraturan Daerah, Jakarta: Dirjen Perundang-Undangan.hlm 16 ${ }^{22}$ Ibid menurut Undang-Undang No. 12 Tahun 2011 Pasal 92 ayat (1) Penyebarluasan Prolegda dilakukan oleh DPRD dan Pemerintah Daerah sejak penyusunan Prolegda, penyusunan Rancangan Peraturan Daerah, pembahasan Rancangan Peraturan Daerah, hingga Pengundangan Peraturan Daerah. Pasal 92 ayat (2) Penyebarluasan sebagaimana dimaksud pada ayat (1) dilakukan untuk dapat memberikan informasi dan/atau memperoleh masukan masyarakat dan para pemangku kepentingan.

\section{Akses Partisipasi ${ }^{23}$}

Partisipasi publik dalam Undang-Undang No. 12 Tahun 2011, telah diatur secara tegas dalam Pasal 96 yang menyatakan masyarakat berhak memberikan masukan secara lisan dan/atau tertulis dalam Pembentukan Peraturan Perundangundangan. Masukan secara lisan dan/atau tertulis dapat dilakukan melalui: a. rapat dengar pendapat umum; b. kunjungan kerja; c. sosialisasi; dan/atau d. seminar, lokakarya, dan/atau diskusi.

Partisipasi masyarakat pada saat pembahasan di DPRD dapat dilakukan sesuai dengan Peraruran Tata Tertib DPRD. Dengan akses partispasi memungkinkan masyarakat untuk menyampaikan aspirasi atau menyumbangkan pemikirannya terhadap suatu kebijakan yang akan diambil oleh Pemeritah Daerah.

Dengan adanya pengaturan tersebut pemerintah, pemerintah daerah provinsi, kabupaten dan kota dalam pembentukan peraturan perundang-undangan memberikan

${ }^{23} \mathrm{Ibid}$ 
hak partisipasi terlebih dahulu kepada masyarakat untuk menyampaikan gagasannya melalui mekanisme hukum yang telah ditentukan.

Pembentukan Perda diperlukan adanya aspek keterbukaan yaitu pemberian kesempatan kepada masyarakat baik dari unsur akademisi, praktis maupun dari unsur masyarakat terkait lainnya untuk berpartisipasi baik dalam proses perencanaan, persiapan, penyusunan dan/atau dalam pembahasan Raperda dengan cara memberikan masukan atau saran pertimbangan secara lisan atau tertulis dengan ketentuan Peraturan Perundang-Undangan. Keberadaan aspek ketebukaan dapat dilihat pada ruang partisipasi masyrakat seperti :

(1) Pembentukan peraturan di pusat maupun daerah begitu marak dengan aneka dampaknya.

(2) Ada ruang kebebasan, muncul kesadaran publik untuk berperan dalam pembuatan kebijakan publik.

(3) Trend internasional mendorong good governance dimana partisipasi masyarakat menjadi prasyarat utamanya, dan

(4) Ada kesadaran pemerintah, DPR/DPRD tentang pentingnya pelibatan masyarakat dalam pembuat kebijakan.

Jadi sangat jelas, hak masyarakat partisipasi dalam pembentukan Undang-Undang atau Perda merupakan amanat UUD, yang pada akhirnya menghasilkan Perda yang transparansi dan partisipasi dalam-rangka penyelenggaraan Pemerintahan Daerah.

\subsection{Tujuan dan Prasyarat Partisipasi}

Tujuan dasar peranserta masyarakat adalah mengahasilkan masukan dan persepsi yang berguna dari warganegara dan masyarakat yang berkepentingan (public interest) dalam rangka meningkatkan kualitas pengambilan keputusan, karena dengan melibatkan masyarakat yang berpotensi terkena dampak kebijakan dan kelompok kepentingan (interest groups), para pengambil keputusan dapat menangkap pandangan, kebutuhan dan pengharapan dari masyarakat dan kelompok tersebut, untuk kemudian menuangkan kedalam konsep. ${ }^{24}$

Partisipasi masyarakat juga merupakan pemenuhan terhadap etika politik yang menempatkan rakyat sebagai sumber kekuasaan dan kedaulatan. ${ }^{25}$ Bernadinus Steni, ${ }^{26}$ mengatakan Partisipasi masyarakat dilaksanakan di era otonomi daerah karena dua alasan yaitu: pertama, amanat konstitusi, dan kedua, pelaksanaan kewenangan mengatur dan mengurus oleh pemerintah daerah. Pelaksanaan partisipasi masyarakat dalam era desentralisasi sebetulnya merupakan partisipasi yang given (diberikan). Meskipun demikian, dalam konteks sejarah ketatanegaraan, partisipasi sekarang merupakan pembaharuan atas praktik sentralisasi di masa lalu.

24 Mahendra Putra Kurnia, dkk. 2007, Pedoman Naskah Akademik Perda Partisipatif. Yogyakarta: Kreasia Total Media (KTM). hlm 41

${ }^{25}$ Ibid

${ }^{26}$ Bernadinus Steni, 2004. Desentralisasi, Koordinasi dan Partisipasi Masyarakat dalam Pengelolaan Sumberdaya Alam Pasca Otonomi Daerah dalam http://www.huma.or.id. hlm 13 
Hakikat pentingnya partisipasi masyarakat dalam pembentukan Perda menurut $\mathrm{Ni}$ Made Ari Yuliartini Griadhi dan Anak Agung Sri Utari, ${ }^{27}$ adalah: (a) Memberikan landasan yang lebih baik untuk pembuatan kebijakan publik dalam menciptakan suatu good governance. $^{28}$ (b) Memastikan adanya implementasi yang lebih efektif karena warga mengetahui dan terlibat dalam pembuatan kebijakan publik. (c) Meningkatkan kepercayaan warga kepada eksekutif dan legislatif, dan (d) Efisiensi sumber daya, sebab dengan keterlibatan masyarakat dalam pembuatan kebijakan publik dan mengetahui kebijakan publik, maka sumber daya yang digunakan dalam sosialisasi kebijakan publik dapat dihemat.

Satjipto Rahardjo mengusulkan untuk menjaga netralitas suatu hukum, perlu adanya transparansi dan partisipasi (lebih besar) dalam pembuatan hukum. Kedua hal tersebut kemudian diangkat sebagai asas dalam pembuatan hukum untuk kemudian dilakukan elaborasi lebih lanjut kedalam prosedur dan mekanismenya. $^{29}$

27
Lihat
http://ejournal.unud.ac.id/abstrak/partisipasi
$\frac{\% 20 \text { masy\%20_md\%20ari\%20yuliarini\%20 }}{\& \% 20}$
$\frac{\text { aasri\%20utari_\%20jan\%20208\%20wr(1).pd }}{28}$

http://en.wikipedia.org/wiki/Good_governan ce di unduh tanggal 6 Oktober 2011

${ }^{29}$ Satjipto Rahardjo, 1998. Mencari Model Ideal Penyusunan Undang-Undanh yang Demokratis (Kajian Sosiologis). Makalah Disampaikan dalam Seminar Nasional Mencari Model Ideal Penyusunan UndangUndang yang Demokratis dan Kongres Asosiasi Sosiologi Hukum Indonesia. Semarang 15 - 16 April 1998.

\begin{abstract}
Prasyarat dari pelaksanaan partisipasi adalah Pertama: Pemerintahan Daerah baik pemerintah daerah maupun DPRD harus terbuka (dengan kebijakan yang berdasarkan kebutuhan masyarakat lokal) keterbukaan adalah kunci, karena demokrasi identik dengan keterbukaan. Kedua: Kapasistas lokal yang memungkinkan masyarakat lokal dapat berhubungan dengan Pemerintah, dan terlibat dalam proses pembentukan kebijakan lokal,melobi kepentingan mereka, dan membangun jaringan.
\end{abstract}

\subsection{Pandangan Prolegda}

Pandangan secara filosofis Prolegda sebagai pembaharuan hukum daerah yang memiliki kedudukan yang strategis, sebagai landasan dan perekat pembangunan di daerah, yang bermakna teraktualisasikannya fungsi hukum sebagai alat rekayasa pembangunan (law as a tool of social engineering), instrumen penyelesaian masalah (dispute resolution) dan instrumen pengatur perilaku masyarakat (social control).

Maksudnya melalui Prolegda, dapat dilakukan penataan sistem hukum secara terencana, menyeluruh, terpadu dan sistematis di daerah, yang senantiasa berdasarkan cita-cita Proklamasi, Pancasila dan konstitusi yang menyatakan Negara Indonesia adalah negara hukum (rechstaat) sebagaimana tertuang dalam Pasal 1 ayat (3) UUD 1945. Sebagaimana yang telah dibahas di bab kedua, prinsip negara adalah berarti menjunjung tinggi supremasi hukum, persamaan kedudukan dihadapan hukum, serta menjadikan hukum sebagai landasan operasional dalam menjalankan sistem penyelenggaraan pemerintahan di bidang kehidupan bermasyarakat, berbangsa dan bernegara. Pandangan filosofis Prolegda sebagai bagian dari pembangunan hukum yang merupakan 
instrumen perencanaan program pembentukan Perda yang disusun secara terencana, terpadu dan sistematis.

Pandangan sosiologis Prolegda diarahkan untuk memenuhi kebutuhan masyarakat, maka perlu dibuat peraturan mengenai pembentukan peraturan perundangundangan yang dilaksanakan dengan cara dan metode yang pasti, baku, dan standar yang mengikat semua lembaga yang berwenang membentuk peraturan perundangundangan. ${ }^{30}$ Artinya pandangan sosiologis Prolegda melihat secara objektif pelaksanaan program pembangunan daerah berdasarkan visi misi Kepala daerah secara umum yang menggambarkan masih belum menunjukkan hasil pembangunan hukum yang sesuai dengan harapan dan rasa keadilan masyarakat, yaitu hukum yang sungguh-sungguh memihak kepentingan rakyat, hukum yang tidak hanya melindungi kepentingan orang perseorangan dan kelompok atau golongan tertentu, dan hukum yang tetap mengimplementasikan nilai-nilai dan norma hukum yang hidup di dalam masyarakat.

Pandangan sosiologis pembentukan Prolegda, sesuai teori perundang-undangan dan teori politik hukum dapat dirumuskan menjadi beberapa hal yaitu: pertama, materi hukum, ditemukan materi hukum yang saling tidak hamonis dan tumpang-tindih dan tidak konsisten, baik secara vertikal maupun horizontal, belum menunjukkan komitmen dan karakter yang responsif terhadap masalah perlindungan hak asasi manusia, masyarakat lemah dan marginal, nilai keadilan jender, serta proses

${ }^{30}$ Penjelasan Undang-Undang No. 12 Tahun 2011, cit op hlm 1. pembentukannya yang kurang aspiratif dan partisipatif oleh pembentuk Perda. Kedua, aparatur hukum, antara lain: kurang memliki integritas, moral dan profesionalisme aparat penegak hukum, serta belum terwujudnya lembaga hukum yang kuat dan berwibawa. Ketiga, persoalan materi, sarana dan prasarana hukum berdampak pada permasalahan kesadaran hukum masyarakat, yaitu rendahnya kepercayaan masyarakat terhadap hukum yang ditandai dengan terputusnya hubungan atau terjadi kesenjangan antara norma-norma hukum dengan perilaku masyarakat.

\subsection{Partisipasi Prolegda}

Penyusunan suatu peraturan perundang-undangan berlangsung dalam struktur sosial tertentu dan demikian merupakan bagian dari proses sosial yang lebih besar, untuk itu penyusunan sebuah peraturan perundang-undangan tidak secara otomatis berjalan lancar, manakala struktur sosial dimana perbuatan itu berlangsung tidak demokratis atau sangat tergantung dari kondisi masyarakat. ${ }^{31}$ Akhirnya peran partisipasi semakin penting dalam proses pengambilan keputusan setelah dikampanyekan good govenrnance oleh Bank Dunia.

Karakteristik good governance atau tata kelola pemerintahan yang baik atau kepemerintahan yang baik adalah partisipasi. ${ }^{32}$ Partsipasi di

31 Sirajuddin, dkk. 2007. Legislative Drafting: Pelembagaan Metode Partisipatif dalam Pembentukan Peraturan PerundangUndangan. Malang: In-TRANS Publishing. hlm 185

32 Jazim Hamidi, Kemilau Mutik, 2011. Legislatif Drafting; Seri Naskah Akademik Pembentukan Perda. Yogyakarta; Total Media. hlm 54 
bangun dibangun atas dasar kebebasan bersosialisasi dan berbicara serta berpartisipasi secara konstruktif. ${ }^{33}$

Pembentukan Prolegda oleh DPRD dan Pemerintah Daerah dapat menggunakan model Musyawarah Rencana Pembangunan (Musrenbang) daerah yang selama ini digunakan dalam membuat rencana pembangunan daerah dan rencana pembuatan APBD, sehingga makna musrenbang dalam proses Prolegda adalah: 1) Bagian dari jaring aspirasi masyarakat untuk mencapai visi dan pemahaman bersama mengenai program pembangunan dan kerangka regulasi yang diperlukan. 2) Mengefektifkan penyelenggaraan pemerintahan. 3) Menghasilkan Perda yang benarbenar sesuai dengan kebutuhan pembangunan di daerah yang bersangkutan, dan 4) Melahirkan Perda yang terencana dan menyatu dengan program pembangunan daerah pada umumnya.

Selain itu, mekanisme partisipasi dalam pembentukan Prolegda dapat menggunakan pola:

1) Mengikutsertakan anggota masyarakat yang ahli, independen dalam tim/kelompok kerja dalam penyusunan Prolegda.

2) Melakukan public hearing melalui seminar, diskusi, lokakarya atau mengundang pihak-pihak yang berkepentingan dalam rapat penyusunan Perda atau musyawarah rencana Pembangunan.

3) Melakukan uji sahih terhadap Prolegda;

${ }^{33}$ Ibid
4) Melakukan jajak pendapat dan kontak publik melalui media masa; dan

5) Melalui lembaga pemberdayaan Masyarakat kelurahan (LPMK) atau membentuk forum warga peduli Prolegda.

Pembentukan dan penyusunan Prolegda harus memberikan ruang partisipasi masyarakat sehingga outcome Perda menjadi berkualitas yang akhirnya Perda mencerminkan kebenaran, keadilan, akomodatif dan aspiratif serta dapat dilaksanakan secara bersama-sama antara pembuat kebijakan dan yang terkena dampak kebijakan.

\section{PENUTUP}

Problematika dari partisipasi masyarakat dalam pembentukan Peraturan Daerah meliputi tiga hal yaitu : permasalahan yuridis, birokrasi dan masyrakat. Partisipasi merupakan pemberian ruang terhadap hak masyarakat untuk memberi masukan dalam Prolegda, dengan secara bersamaan mewajibkan Pemerintah daerah dan Dewan Perwakilan Rakyat Daerah (DPRD) mempermudah masukan mengenai Pembentukan Prolegda. Prolegda merupakan dokumen perencanaan yang dipersiapkan secara dan bersama-sama oleh lembaga pemerintahan daerah dengan mengikuti ketentuan hukum yang sudah ditentukan.

Pemberlakuan otonomi daerah secara normatif, merupakan peluang membuka ruang partisipasi masyarakat dalam proses penyusunan dan implementasi kebijakan. Maka secara konseptual partisipasi merupakan implementasi dari sistem pemerintahan demokrasi 
dari rakyat oleh rakyat dan untuk rakyat. Peran serta masyarakat dalam proses penyusunan Prolegda dilaksanakan dengan memperhatikan asas keterbukaan dan prinsip akses informasi serta partisipasi. Dikarenakan hak masyarakat dalam berpartisipasi telah dijamin dan diberikan dalam Undang-Undang atau Perda yang merupakan amanat UUD, yang pada akhirnya akan dihasilkan Perda yang transparansi dan partisipasi dalam penyelenggaraan pemerintahan Daerah.

Kedepan disarankan kepada pemerintahan daerah untuk membuat Perda tentang Transparansi dan Partisipasi masyarakat sehingga adanya penjaminan dan perlindungan hak masyarakat dalam ikut-serta dalam pemerintahan melalui partisipasi masyarakat.

\section{DAFTAR PUSTAKA}

\section{Akmal Boedianto, 2010. Hukum Pemerintahan Daerah: Pembentukan Perda APBD Partisipatif. Yogyakarta: LaksBang PRESSindo.}

Erwan Agus Purwanto, Pelayanan

Publik Partisipatif, dalam

Agus Dwiyanto, 2006.

Mewujudkan Good

Governance Melalui

Pelayanan Publik. Yogyakarta; Gajah Mada University Press.

Sri Soemantri M., 1992, Bunga Rampai Hukum Tata Negara Indonesia, Bandung: Alumni.

Philipus M. Hadjon, 1997.

Keterbukaan Pemerintahan dalam Mewujudkan

Pemerintahan yang

Demokratis, Pidato, diucapkan dalam Lustrum III Ubhara

Surya.

Satjipto Rahardjo, 1998. Mencari

Model Ideal Penyusunan

Undang-Undanh yang

Demokratis (Kajian

Sosiologis). Makalah

Disampaikan dalam Seminar

Nasional Mencari Model Ideal

Penyusunan Undang-Undang yang Demokratis dan Kongres

Asosiasi Sosiologi Hukum

Indonesia. Semarang $15-16$

April 1998.

Maria Farida. 2005. Kedudukan

Peraturan Daerah dalam

Sistem Hukum di Negara

Republik Indonesia. Makalah

disajikan pada acara Temu

Konsultasi Penyusunan

Program Legislasi Daerah, yang diselenggarakan oleh

Badan Pembinaan Hukum

Nasional, Departemen Hukum dan HAM, di Sanur, Bali.

Khairul Muluk, 2006. Desentralisasi dan Pemerintahan Daerah. Jakarta: Penerbit Bayumedia.

Mahendra Putra Kurnia, dkk. 2007, Pedoman Naskah Akademik

Perda Partisipatif. Yogyakarta:

Kreasia Total Media (KTM).

Sirajuddin, dkk. 2007. Legislative Drafting: Pelembagaan Metode Partisipatif dalam Pembentukan Peraturan Perundang-Undangan. Malang: In-TRANS Publishing.

Yuswanto. 2009. Otonomi Daerah Dalam Konstitusi., Bahan ajar perkuliahan otonomi daerah Pasca Sarjana FH UNILA.

Departemen Hukum dan Hak Asasi Manusia RI, 2009. Panduan

Praktis Memahami 
Perancangan Peraturan

Daerah, Jakarta: Dirjen

Perundang-Undangan.
Undang-Undang No. 14 Tahun 2008 tentang Keterbukaan Informasi Publik

R. Siti Zuhro, Lilis Mulyani, Fitria, 2010. Kisruh Peraturan

Daerah: Mengurai Masalah dan Solusinya. Yogyakarta: Penerbit Ombak.

Jazim Hamidi, Kemilau Mutik, 2011. Legislatif Drafting; Seri Naskah Akademik Pembentukan Perda. Yogyakarta; Total Media.

Lihat Undang-Undang No. 12 Tahun 2011 tentang Pembentukan Peraturan PerundangUndangan (Lembaran Negara Republik Indonesia Tahun 2011 Nomor 82, Tambahan Lembaran Negara Republik Indonesia Nomor 5234).

Undang-Undang No. 32 Tahun 2004 tentang Pemerintahan Daerah, (Tambahan Lembaran Negara RI Nomor 4437).

http://id.wikipedia.org/wiki/Demokra si, diunduh tanggal 6 oktober 2011.

http://ejournal.unud.ac.id/abstrak/par tisipasi\%20masy\%20_md\%20a ri\%20yuliarini $\% 20 \& \% 20$ aasri\%20utari\%20jan\%20208 \%20wr(1).pdf

http://en.wikipedia.org/wiki/Good_g overnance di unduh tanggal 6 Oktober 2011

Bernadinus Steni, 2004. Desentralisasi, Koordinasi dan Partisipasi Masyarakat dalam Pengelolaan Sumberdaya Alam Pasca Otonomi Daerah dalam http://www.huma.or.id. 